University for Business and Technology in Kosovo

UBT Knowledge Center

UBT International Conference

2013 UBT International Conference

Nov 2nd, 12:30 PM - 12:45 PM

\title{
The Development of the Tax System in Albania
}

\author{
Luciana Koprencka \\ University "Ismail Qemali" Vlore \\ Fioralba Velaj \\ University "Ismail Qemali" Vlore \\ Migena Petani \\ University "Ismail Qemali" Vlore
}

Follow this and additional works at: https://knowledgecenter.ubt-uni.net/conference

Part of the Business Commons

\section{Recommended Citation}

Koprencka, Luciana; Velaj, Fioralba; and Petani, Migena, "The Development of the Tax System in Albania" (2013). UBT International Conference. 41.

https://knowledgecenter.ubt-uni.net/conference/2013/all-events/41

This Event is brought to you for free and open access by the Publication and Journals at UBT Knowledge Center. It has been accepted for inclusion in UBT International Conference by an authorized administrator of UBT Knowledge Center. For more information, please contact knowledge.center@ubt-uni.net. 


\title{
The Development of the Tax System in Albania.
}

\author{
Luciana Koprencka ${ }^{1}$, Fioralba Velaj ${ }^{2}$, Migena Petani ${ }^{3}$ \\ ${ }^{13}$ Department of Finance, University "Ismail Qemali" Vlore \\ ${ }^{2}$ Department of Management, University "Is mail Qemali" Vlore
}

\begin{abstract}
Development of the tax system in all countries where the economic and political responses.In Albania as a totalitarian society, through the tax system was intended total abolition of private property by changing the structure of income in favor of the state sector income. The tax system contained local and national system of taxes, which were mandatory defined by law, poured on the budget, in a certain amount the amount and period of time. Finances during socialism period were estimated as the most important levers of economic management. They rely on planning and centralization, provided only in terms of the way socialist production, in terms of the existence of socialist social property of the means of production. The democratic changes in the early 90 's brought a series of changing in the economic and financial system. The Reforms that were undertaken, in this period were both administrative and fiscal ones. They intended to build the foundations of a new financial system, which had to res pond to rapid economic and financial changes.
\end{abstract}

Keywor ds: fiscal policy, fiscal burden, income tax, value added tax.

\section{Introduction}

\section{History of the development of the tax system in Albania.}

A developed human society operates on the bas is of guarantees and equaldistribution of public goods. In the so called totalitarian systems, the state had in his hands the whole capital, income in kind, but also human resources were in his hands. Therefore taxation of citizens was unnecessary, because private property almost entirely was eliminated. While in capitalist society, the state has in its possession a small part of national wealth, therefore it is necessary to create income which are needed to meet the obligations of the state towards its own citizens (budget employees salaries, pensions, investments in infrastructure, schools, hospitals, etc.).But will flow from these financial resources necessary for the state? The main sources used by the state to create public goods, are taxes and fees. According to Albanian legislation: Tax is an obligatory and irreversible payment to the state, which include administrative penalties and interest for late payment set out in law. Tax is an obligatory contribution to be paid by any person who directly benefits the public service. Evolution of the tax system in Albania has passed through several stages by responding to country's Economic Development, first-period begins with the declaration of independence in 1912 until 1944. The second period, coincides with the establishment of the socialist system,1944-1990. The third period, the resumption of the tax system, during which financial and tax policies have evolved a lot, from 1991 to 2012.

\subsection{The historical period from 1912 to 1944.}

The Albanian state after the declaration of the independence, inherited a backward tax system, the main base of the Albanian state income taxes were direct, placed on manufacturers at the time of their creation. They were composed of one tenth (land tax on products) Xhelepi (tax on Livestock), vergjia (tax on buildings and lands), license tax and profit tax.

During this period were set customs duties on goods, was changed the import tax on tobacco by $30 \%$, increased, decreased or canceled export taxes in order to protect the domestic production. Laws and orders came out of the export ban of gold, silver, brass and fan. Reorganization of State in 1925, was followed by taking a series of measures. 
During this period was forced the collection of delayed obligations, was created the first Albanian coin (Albanian gold francs).

The introduction of foreign capital, became the official policy of the government of King Zog. During 1931-1936, foreign capital, especially the Italian one, dictated to Albanian Governments the accomplishment of an agreement for the union of the Customs. This union at that time, would include the Albanian economy in Italian economic system and also the opening without limitation the Italian capital. Customs Union will be a direct hit in the interests of the newly established Albanian bourgeoisie. But the state budget, will be deprived of an important source of income, as were customs revenue.

At the same time it would increase the financial dependence, Albanian from Italian finance. King Zog formally accepted the agreement, but later he refused it. The improvement of the tax system was based on " The Kingdom Statute fundamental question" who ruled the basic principle that tax is an obligation for people to cope with the general state expenditures.

\subsection{The Historical Period, 1945-1990}

This period begins with the end of the Second World War and ends with the fall of socialist system in Albania. Tax policy based on the principles of Marxist-Leninist classics weakened the private property, by initially setting very high progressive taxes on the rich (to $80 \%$ ), aiming at weakening of their economic as well as creating a new system of relations of socialist. The postwar government through the tax system aimed at the total elimination of private property by changing the structure of income in favor of the state sector income.

The tax system contained local and national system of taxes, which were mandatory defined by law, poured on the budget, in a certain amount the amount and period of time. In Albania during the monism years, was established a unique and complete system of financial authorities. It consisted of organizations of general finance, which included sections Finance and Audit sections, the State Bank, Agricultural Bank and the Ins titute of Cash Savings and Insurance. Organizations financials enterprises, cooperatives and branches of the economy of finance and accounting in economic enterprises, the agricultural cooperatives, departments of finance and audit control - ministerial and other central institutions. Albanian state was the main owner of the means of production and the leader of the economy. The finances during socialism were evaluated as the most important levers of economic management. They rely on planning and centralization, which provided only in terms of the way socialist production, in terms of the existence of socialist social property of the means of production and the state of the dictatorship of the proletariat. The distribution of monetary resources in a centra lized manner and according to a unique policy for the whole country provides centralized insured the formation of monetary resources in the hands of the socialist state.

The tax system was classified on the bas is of residence in the population of the city and the village. The taxation system in the city included income tax derived from the operation of artisans, merchants, tax on income from wages and additional remuneration of employees, taxes on income from single women and income tax from married with children. The taxation system of the village included income tax from individual agricultural economies, income tax from kulaks, income tax yards from members of agricultural cooperatives, the tax on alcoholic beverages.

Besides the town and village taxes are applied several types of local taxes such as taxes on holders of means of transport, such as cars, motorcycles, bicycles, wagon, tax thick animals, market taxes and weight measurement, cleaning fees, taxes the exercise of the profession and the acts and stamp duty. In 1976 through the adoption of the Constitution was achieved complete elimination of private property, Albania was considered the only place in the world without taxes and tariffs, taxes were hidden in centralized prices of goods and services supplied by the state sector and cooperatives of the economy.

\subsection{The Historical Period 1991-2012}

Democratic changes also brought a number of changes in the economic and financial system. Reforms that took place in this period were comprised of administrative and fiscal reforms, these were intended to build the foundations of a new financial system, which had to respond to rapid changes in economic and financial. The transformation of the financial system, which began in July 1991, at that time consisted of two types of reform, fiscal reform and administrative reform. These reforms were an 
intensive process of creating from the foundation of a new financial system, which was implemented to respond quickly to rapid economic changes restructuring took State Bank, the creation of foreign banks, cutting ne bank-notes, the privatization of the Saving Bank.

\section{The Tax Structure}

Fiscal legislation defines taxes on taxable basis, they consist of taxes on incomes, from taxes and spending on capital and property taxes. The main criterion in this division is economic source. Also in the tax theory, are used different practices related to the tax rate, they may be proportionate, progressive and regressive. In general, taxes are viewed as a necessary evil. It is said that only two things in life are certain, death and taxes. The new tax system after years 1990, was drafted by virtue of the imposition of direct and indirect taxes.

Albania's tax system is built in such a way, where taxes are paid by the companies where individuals are employed. They calculate and maintain the income tax they pay their employees and for the state. They also collect and pay VAT. While other taxes like income tax, excise, turnover tax, which are actually paid by the customer, are invisible and hidden in the prices of goods and services. In the same way social security contributions are split between employee and employer and paid by the latter. Often businesses pay social insurance on lower wages than workers receive in reality, this is done to reduce business costs.

Tax payers, have a different approach to fiscal experts as regards the taxation system. Individuals complain about taxes, they pay tax on income, whether businesses pay the tax on profits, they also pay the tax on dividends, the amount of direct taxes and indirect taxes, visible and invisible, according to them, they are taxed in any moment in every link. While fiscal specialists believe that we actually have a lower level of taxation compared to other countries in the region. Recently been made, as never before, a big debate by representatives of political parties on the level and form of taxation in our country. The flat tax or progressive tax on income, increase or decrease of the VAT tax base, increase or reduction of income taxetc. These dilemmas are constant subject of discussion by various researchers in the country. Several studies made by institutions like The Heritage Foundation, Freedom House and the Fraser Institute have concluded that the higherthe fiscalfreedom, and the low taxes in a country the more economically powerful it is.

Table 1. The percentage of the income tax to gdp.

\begin{tabular}{llllllllllll}
\hline $\begin{array}{l}\text { Percentage } \\
\text { to }\end{array}$ & $\mathbf{2 0 0 0}$ & $\mathbf{2 0 0 1}$ & $\mathbf{2 0 0 2}$ & $\mathbf{2 0 0 3}$ & $\mathbf{2 0 0 4}$ & $\mathbf{2 0 0 5}$ & $\mathbf{2 0 0 6}$ & $\mathbf{2 0 0 7}$ & $\mathbf{2 0 0 8}$ & $\mathbf{2 0 0 9}$ & $\mathbf{2 0 1 0}$ \\
GDP(\%) & & & & & & & & & & & \\
\hline $\begin{array}{l}\text { Total } \\
\text { income }\end{array}$ & 25.0 & 25.0 & 24.8 & 24.1 & 24.5 & 25.2 & 26.0 & 26.0 & 26.8 & 26.1 & 26.5 \\
$\begin{array}{l}\text { Tax income } \\
\text { From }\end{array}$ & 19.9 & 19.6 & 20.7 & 20.9 & 22.1 & 22.6 & 23.3 & 23.6 & 24.3 & 23.7 & 23.5 \\
customs & 15.5 & 15.0 & 15.6 & 15.7 & 16.4 & 16.6 & 17.6 & 18.3 & 18.9 & 18.3 & 18.2 \\
and & & & & & & & & & & & \\
taxation & & & & & & & & & & & \\
VAT & 7.3 & 7.1 & 7.4 & 7.3 & 7.7 & 7.9 & 8.4 & 9.1 & 9.8 & 9.6 & 9.3 \\
Tax over & 1.6 & 1.8 & 2.0 & 1.9 & 2.2 & 2.9 & 2.5 & 2.2 & 1.7 & 1.5 & 1.4 \\
profit & & & & & & & & & & & \\
Akcizat & 1.7 & 1.6 & 1.5 & 1.8 & 2.1 & 2.3 & 2.6 & 3.0 & 3.0 & 2.9 & 3.1 \\
\hline
\end{tabular}

As it is seen in the table, the income tax in our country expresses about $25 \%$ of GDP, but it has been about $2 \%$ smaller in the last two years, especially in 2013 as a result of some changes in the taxstructure such as the increase of the minimum limit of the taxed wages, and some exceptions fromVAT.Albania has got the lowest tax revenue to GDP in the region. Meanwhile, Bos nia and Herzegovina (46\%) is 
ranked in the first place followed by Montenegro (43\%), Serbia (39.5\%), Croatia (38.7\%), Greece (36.9\%), Turkey (39.7\%), Macedonia (30.3\%) and Kosovo (29.7\%). (Source: IMF)

\subsection{The Personal income tax.}

Personal income tax in Albania in about includes about 17\% of total revenue and only 1-2\% of GDP. However, there is much discussion about it because it affects the personal income especially the income from employment. Albania has been using the progressive tax system especially in the last 14 years, from 1993 to 2007 . We removed the high tariff which was about $25 \%$ or $30 \%$ from the package of the year 2006 leaving it in a maximum fee of $20 \%$ and another new tariff of about $1 \%$ for the minimum income.

Table 2 The progressive income tax

\begin{tabular}{lll}
\hline Taxable income/month & Employee's personal income tax \\
\hline 0 & to 14,000 & $1 \%$ \\
14,001 & 40,000 & 140 lek plus $5 \%$ amount over 14,000 \\
40,001 & 90,000 & 1,440 lek plus $10 \%$ amount over 40,000 \\
90,001 & 200,000 & 6,440 lek plus $15 \%$ amount over 90,000 \\
& & 22,940 lek plus $20 \%$ amount over 200,000 \\
\hline 200,001 & more & Source: Ministry of Finance
\end{tabular}

We have been applied the "flat tax" where the personal income and the profit are taxed about $10 \%$, in Albania since January the $1^{\text {st }} 2008$. The progressive tax system is used in over 164 from the total 196 countries in the world such as: EU, U.S., Japan, Brazil, Australia, China, Egypt, Kosovo etc., while the "flat tax" began to expand after the year 1990. Estonia was the first to use this system in 1994, followed by other Baltic countries, Russia in 2001 and the other republics of the former Soviet Serbia in 2003 and the former Yugoslavia, Slovakia in 2004.Flat tax was firstly applied in Albania during 2008 after two years of debates. The tax refers to the application of a $10 \%$ levied on the profit or on the total personal income. Application of flat tax in our country was associated with a series of measures to eventual avoid negative effects of this tax.

Table 3 Employee's personal income tax (based on flat tax)

\begin{tabular}{llll}
\hline Taxable income/month & $\begin{array}{l}\text { Employee's } \\
\text { income tax }\end{array}$ & personal \\
\hline 0 & to 10.000 & $0 \%$ & \\
10.001 & 30.000 & $\begin{array}{l}+10 \% \text { of amount over } \\
10.000 \text { lek }\end{array}$ & \\
\hline 30.001 & more & $10 \%$ of amount over & \\
\hline
\end{tabular}

Source: Ministry of Finance

By applying the flat tax it was intended to reduce the tax burden of the workers, but in fact the it pl increased the fiscal burden for the majority of employers.

Table 4 Amount of tax paid by progressive and flat tax.

\begin{tabular}{|c|c|c|c|}
\hline $\begin{array}{l}\text { Taxable } \\
\text { income }\end{array}$ & $\begin{array}{l}\text { By } \\
\text { progressive } \\
\text { tax }\end{array}$ & $\begin{array}{ll}\text { By flat } \\
\text { tax }\end{array}$ & Difference \\
\hline 18.000 & 340 & 800 & -460 \\
\hline 25.000 & 690 & 1.500 & -810 \\
\hline 45.000 & 1.940 & 4.500 & -2.560 \\
\hline 70.000 & 4.440 & 7.000 & -2.560 \\
\hline 90.000 & 6.440 & 9.000 & -2.560 \\
\hline
\end{tabular}




\begin{tabular}{llll}
\hline 105.000 & 8.690 & 10.500 & -1.810 \\
140.000 & 13.940 & 14.000 & -60 \\
160.000 & 16.940 & 16.000 & -940 \\
200.000 & 22.940 & 20.000 & -2.940 \\
\hline \multicolumn{4}{c}{ Source: Albanian Tax Office Income Report }
\end{tabular}

So we can see that the "flat tax" reduces the incomes of the first groups which is the majority, and favors and the fifth group which has got higher incomes.Considering that the most wages consist of 30-90.000 Lek we can see that the system of the "flat tax" damages the individuals with low middle personal income and favors the individuals with higher incomes. Another change took place at the level of income tax in summer 2013. There were changes in the boundaries of income tax of the salary level, excluding the income tax on wages up to 30,000 lek (Albanian currency). This decision had a positive effect to the a state budget by 2.5 billion, and about 220 thousand people benefited from this change.Another change on the personal income tax liability is the removal of personal income integral declaration, which was introduced in the fiscal package in 2005. This change was thought to have positive effects in fighting the tax evasion but it was not realised because it was considered premature. The new government has promised to practice the progressive taxation so that to reduce the fiscal burden on the poor and the middle class of the population and to raise taxes on the wealthy people with higher incomes. Fieldhouse (2013) has concluded that the progress ive tax increase budget revenues, and improves the public debt and inequality without any negative impact on economic growth.Reduction of taxes, tax procedures and the fairness of tax administration are very important for the development of the economy and welfare of the country. They are also the key for the stability of the economy and the attraction of the foreign investors in Albania.

\subsection{The Income tax}

The reduction of the income tax from $20 \%$ to $10 \%$ in 2008 decreased the tax of the business income in the state budget. This reduction intended to encourage the creation of new businesses either foreign or domestic so that to increase the income in the state budget, but in fact it was not successful. It resulted in lower revenues, so it was $2.9 \%$ of GDP in 2009 versus to $3 \%$ of GDP in 2008.This flat tax had a negative effect on the poor and middle classes and increased the personal income of the businesses. It didn't increase the income in the state budge. It also increased the difference between the rich and the poor.

\subsection{The Valued Added Tax (VAT)}

The value added tax is a tax on consumption and costs, and for the first time it was applied in France in 1954. VAT also existed in early Egyptian and Greek civilizations and Athens like a tax on sales.It was reflected in the legis lation of many countries after World War and continued to appear very quickly in other countries. Since 1967 it has been applied in the majority of countries. The application of VAT has been the most important event in the field of taxation for last 50 years. Being unknown before, in the 50s it became very popular in about 136 countries including France.

The implementation of the VAT developed especially in 90 s because it was applied even by the countries in transition. In Albania it was put into practice for the first time in 1996. In the period 20072012, the value added tax (VAT) occupied the largest share of revenue to the state budget, by about $44-46 \%$. About 78 percent of this tax revenue comes from customs system, while 22 percent of it comes from the tax administration. The VAT includes $9,1 \%$ of GDP. When VAT was put for the first time in Albania in 1996, was valued in 12.5. In September 1997, VAT was increased from 12.5 to 20 percent, close to neighboring countries and beyond. The border remained fixed for many years . VAT, as a tax on the consumer sphere, turned the majority of firms and individuals in great contributors to the state budget. But as an indirect regressive tax, it damages people with lower incomes. The decision that even those who could circulate about 5 million lek in a year had to obey the rules of the Value Added Tax made the small businesses be included in it. This new scheme of taxation, VAT and income tax, was done in an unsuitable moment, when the payment was very problematic. About $25-30 \%$ of the taxpayers don't present their monthly statements, 35-40\% claim credit balance ( do not pay VAT) or declare that they have not done all activities and only $30-40 \%$ actually pay the VAT.Nearly all countries 
of the world operate mainly with a scheme of a Value Added Tax(VAT.) which is different for different goods and services, i.e. with different parameters for the respective goods and services. In Europe and in countries with rich goods and basic services such as food, medicine, education, medical services, electricity, gas etc. the VAT (VAT) is almost reduced to zero.

For example England, one of the most developed countries of the world has got a zero VAT on food. This tax varies from 0 to $5 \%$ in most European countries, and this is done deliberately to protect the people in need as much as possible. The reduction of the VAT for the basket vital foods, medicines and health services, the removal of the VAT on importation of agricultural machinery, reduction or compensation of VAT for the electricity for the consumers of poor families, the exception or reduction of VAT rates for fertilizers, seeds and seedlings for other subjects before being used in agriculture and livestock, are necessary measures to protect high social layer, judging by the poor of the family in our country. Albanians are 8 times poorer than the average families of European zone.

\subsection{The excise}

The incomes from excise are generated by an additional tax called luxury goods. They include goods which are not necessary in everyday life, it is a special type of tax that is applied on either domestic products or foreign ones. Revenue from excise occupy approximately $2 \%$ of GDP in our country . There have been a few changes in fees constituent items, like coffee, drinks, alcohol, tobacco by products, fuel, cosmetics etc. During these years.. Revenue from excise tax for 2012 resulted in 10.5 percent less than forecast and 2.6 percent less than in 2011. The recession has as excise collected from customs and tax administration. Quantities of fuel clearance, beer, cigarettes and coffee, as the most important articles in budget revenues have declined during 2009-2012 although the market demand and consumption have been increasing. From 1 October 2012, according to law 61/2012 " On Excise Taxes in RA ", all excise tax collected and administered by the customs administration. Law has changed the elements of the declaration, payment and control of excise structure for some goods, but not their extent .

\section{Conclusions}

The history of finance in Albania is characterized by a different policies. These financial policies, with their advantages and disadvantages are trying to respond to the economic and political development of the country.

Unlike economics and finance in capitalism, socialism finances rely on planning and centralization, which are provided only in terms of the socialist way of production, in terms of the existence of socialist social property of the means of production and the state of the proletarian dictatorship. The distribution of monetary resources in a centralized manner and according to a unique policy for the whole country used to provide the formation of centralized fund of the monetary resources in the hands of the socialist state.

After the 90s, the tax system experienced a deep legislative reform, either financial or administrative which used to fight the corruption and helped in giving the highest growth and progress to the country. By placing the flat tax was intended to reduce the tax burden on employees but actually placing the flat tax was lowered income groups before, which favors the majority and the fifth group, with higher incomes .

The implementation of the flat tax aimed at the reduction of the tax barrier to help people. But the "flat tax" reduced the incomes of the first groups which was the majority, and favored the fifth group which had got higher incomes. The reduction of the VAT for the basket vital foods, medicines and health services, the removal of the VAT on importation of agricultural machinery, reduction or compensation of VAT for the electricity for the consumers of poor families, the exception or reduction of VAT rates for fertilizers, seeds and seedlings for other subjects before being used in agriculture and livestock, are necessary measures to protect high social layer, judging by the poor of the family in our country. Reduction of taxes, tax procedures and the fairness of tax administration are very important for the development of the economy and welfare of the country. They are also the key for the stability of the economy and the attraction of the foreign investors in Albania. 


\section{References}

1. Agenda Institute "Cragy the tax flat reforms" june

2. Isilda Mara and Edlira Narazani "The effects off flat tax on inequality tax and Informal Employment : The case of Albania” 2011.

3. Hall, Robert and Rabushka, A “ The route to a progressive tax" 1985

4. Chu,K and Davoodi, H and Gupta, S (2000) "Income Distribution and Tax Government Spendig, Policies in Developing Countries".

5. Shah, A and J, Whalley (1990) "Tax Incidence Analysis of Developing Countries: An Alternative View" World Bank Economic Review.

6. Bank of Albania Annual Report (2012)

7. www.minfin.gov.al

8. www.al-tax.org

9. www.tatime.gov.al 